\title{
PENGARUH OUTLET ATMOSPHERE DAN PELAYANAN GERAI TERHADAP PEMBELIAN IMPLUSIF PADA GERAI DALAM LIPPO PLAZA KOTA KENDARI
}

\author{
Muhammad Rizaldi Makmur'; Alasman Mpesau² \\ ${ }^{1}$ Program Studi Manajemen, Fakultas Ekonomi dan Bisnis Islam Universitas Muhammadiyah \\ Kendari \\ ${ }^{2}$ Program Studi Ilmu Hukum, Fakultas Hukum Universitas Muhammadiyah Kendari \\ e-mail: *muhammadrizaldimakmur@febi.umkendari.ac.id, asman.sultra@yahoo.com
}

\begin{abstract}
ABSTRAK: Penelitian ini bertujuan untuk menguji dan menganalisis secara empiris pengaruh atmosphere dan pelayanan gerai terhadap pembelian impulsif pada gerai dalam Lippo Plaza Kendari. Penelitian ini bersifat explanatory yang bermaksud menjelaskan kedudukan variabel-variabel yang diteliti serta hubungan dan pengaruh antara satu variabel dengan variabel lain. Hasil penelitian menunjukkan bahwa: (1) Variabel atmosphere gerai dan pelayanan gerai berpengaruh positif terhadap pembelian impulsif pada gerai Lippo Plaza Kendari. Karena itu, hipotesis penelitian yang diajukan dapat diterima; (2) Variabel atmosphere gerai dan pelayanan gerai berpengaruh secara parsial terhadap pembelian impuls konsumen pada gerai Lippo Plaza Kendari; dan (3) Variabel pelayanan gerai merupakan variabel yang dominan mempengaruhi pembelian impuls pada gerai Lippo Plaza Kendari.
\end{abstract}

Kata Kunci: Suasana Gerai; Pelayanan Gerai dan Pembelian Impulsif.

Abstract: This study aims to test and analyze empirically the effect of atmosphere and service outlets on impulsive buying at outlets in the Lippo Plaza Kendari. This research is explanatory which intends to explain the position of the variables studied and the relationship and influence between one variable with another variable. The results showed that: (1) Variable outlet atmosphere and service outlets had a positive effect on impulsive buying at the Lippo Plaza Kendari outlet. Therefore, the research hypothesis proposed can be accepted; (2) Variable atmosphere of outlets and service outlets partially affect the purchase of consumer impulses at Lippo Plaza Kendari outlets; and (3) The outlet service variable is the dominant variable influencing impulse purchases at the Lippo Plaza Kendari outlet.

Keywords: Outlet Atmosphere; Outlet Services and Impulsive Buying.

\section{PENDAHULUAN}

Masyarakat perkotaan kini dimanjakan oleh kehadiran berbagai pusat perbelanjaan. Bahkan lokasinya kadang-kadang di satu kawasan. Kondisi ini sangat menguntungkan karena masyarakat tinggal memilih gerai mana yang akan dimasukinya. Ritel merupakan mata rantai yang penting dalam proses distribusi barang dan merupakan mata rantai terakhir dalam suatu proses distribusi. Melalui ritel, suatu produk dapat bertemu langsung dengan penggunanya. Industri ritel di sini didefinisikan 
sebagai industri yang menjual produk dan jasa pelayanan yang telah diberi nilai tambah untuk memenuhi kebutuhan pribadi, keluarga, kelompok, atau pemakai akhir. Produk yang dijual kebanyakan adalah pemenuhan dari kebutuhan rumah tangga termasuk sembilan bahan pokok.

Industri ritel di Indonesia memberikan kontribusi yang besar terhadap Produk Domestik Bruto (PDB) dan juga menyerap tenaga kerja dalam jumlah yang besar. Sebagai negara yang membangun, angka pertumbuhan industri ritel Indonesia dipengaruhi oleh kekuatan daya beli masyarakat, pertambahan jumlah penduduk, dan juga adanya kebutuhan masyarakat akan pemenuhan produk konsumsi. Kehadiran industri ritel modern pada dasarnya memanfaatkan pola belanja masyarakat terutama kelas menengah ke atas yang tidak mau berdesak-desakan di dalam pasar tradisional yang biasanya becek atau tidak tertata rapi. Walaupun kehadiran ritel modern ini disoroti dapat mematikan pasar tradisional karena mempunyai keunggulan pada banyak faktor, perkembangannya sendiri dapat dikatakan tidak terbendung.

Gerai merupakan tempat konsumen untuk melakukan pembelian, baik itu terencana maupun tidak terencana. Pembelian terencana adalah perilaku pembelian dimana keputusan pembelian sudah dipertimbangkan sebelum masuk ke dalam gerai, sedangkan pembelian tak terencana adalah perilaku pembelian tanpa ada pertimbangan sebelumnya. Point of Purchase Advertising Institute (POPAI) dalam Astuti dan Fillippa (2008) menyebutkan bahwa sekitar 75 persen pembelian di supermarket dilakukan secara tak terencana. Salah satu jenis pembelian tidak terencana yang sering mendapatkan perhatian adalah pembelian impulsif (impulsive buying). Hal ini disebabkan pembelian impulsif merupakan sebuah fenomena dan kecenderungan perilaku berbelanja meluas yang terjadi di dalam pasar dan menjadi poin penting yang mendasari aktivitas pemasaran.

Data ini juga didukung oleh hasil studi yang dilakukan Nichols et al. dalam Coley dan Burgess (2003) yang menyebutkan 50 persen pembeli di mall berbelanja secara impulsif. Perilaku belanja impulsif juga terjadi di Indonesia, terlihat dari hasil survei yang dilakukan oleh AC Nielsen dalam majalah Marketing/05/V/Mei/2007 yang menyatakan bahwa 85 persen konsumen ritel moderen di Indonesia cenderung untuk berbelanja secara impulsif. Mengingat besarnya pengaruh pembelian impulsif terhadap total penjualan, maka pemasar perlu untuk mengidentifikasi faktor-faktor penyebabnya untuk dapat memformulasikan strategi pemasaran yang tepat (Hausman, 2000). Kecenderungan pola belanja yang juga terjadi saat ini adalah kaitannya dengan motivasi konsumen dalam melakukan kegiatan belanja. Kegiatan belanja pada awalnya dilakukan oleh konsumen dimotivasi oleh motif yang bersifat rasional, yakni berkaitan dengan manfaat yang diberikan produk tersebut (nilai utilitarian) (Ma'ruf, 2006).

Atmosfer berbelanja mempengaruhi keyakinan terhadap produk dan pelayanan yang ditawarkan oleh sebuah gerai ritel (Bateson dan Hoffman dalam Grayson dan McNeill, 2009). Pengaruh ini tidak hanya terbatas pada konsumen tetapi juga terhadap karyawan dalam meningkatkan produktivitas dan menciptakan interaksi positif antara karyawan dan konsumen. Oleh karena itu, atmosfer gerai merupakan salah satu aspek yang penting yang harus dipertimbangkan ketika mengelola tujuan bisnis dan ekspektasi konsumen (Grayson dan McNeill, 2009). 
Lippo Plaza merupakan perusahaan ritel tertua dan terbesar di Indonesia, yang saat ini menguasai pangsa pasar ritel Indonesia sebesar 25 persen. Hasil wawancara terhadap beberapa orang pelanggan Lippo Plaza memperlihatkan bahwa terdapat beberapa alasan utama pelanggan untuk berbelanja di Lippo Plaza yaitu kedekatan lokasi, kelengkapan produk, berada di kawasan one-stop shopping, suasana yang nyaman dan area parkir yang luas. Kedekatan lokasi dan kelengkapan produk ternyata merupakan pertimbangan utama sebagian besar responden dalam menentukan cabang Lippo Plaza yang dipilih sebagai tempat berbelanja. Banyak responden juga mempertimbangkan kenyamanan suasana gerai dan keberadaan gerai di kawasan onestop shopping. Area parkir yang luas tampak bukanlah alasan pentiing responden dalam memilih gerai dalam Lippo Plaza yang dipakai sebagai tempat berbelanja.

Berdasarkan hasil wawancara awal dengan beberapa pengunjung gerai dalam Lippo Plaza Kendari tanggal 20 Maret 2013 pukul 17.30 menyatakan bahwa kecenderungan konsumen dalam mengunjungi gerai dalam Lippo Plaza salah satu disebabkan faktor rekreasi, jalan-jalan dan berbelanja. Menurut beberapa pengunjung bahwa pada awalnya mereka ke gerai dalam Lippo Plaza hanya untuk rekreasi dan berjalan-jalan. Hal ini disebabkan karena desain yang dimiliki oleh gerai-gerai Lippo Plaza membuat para pengunjung tertarik untuk mengunjungi tempat tersebut. Namun secara tidak disengaja terjadilah transaksi pembelian akibat keinginan konsumen terhadap diskon-diskon atau potongan harga serta pajangan-pajangan yang disajikan oleh geraigerai Lippo Plaza membuat mereka secara tidak sengaja untuk membeli berbagai produk yang ada.

Menurut Samuel (2005) bahwa barang-barang yang dibeli secara tidak terencana (produk impulsif) kebanyakan adalah produk dengan harga murah yang tidak terduga. Hal ini dapat disebabkan oleh adanya faktor promosi penjualan di setiap ruang pajang dalam lingkungan berbelanja. Promosi penjualan yang mencakup hadiah, kupon, dan diskon dapat menjadi rangsangan-rangsangan yang mempengaruhi proses pengambilan keputusan, sehingga mempercepat keputusan pembelian konsumen.

Fenomena yang terjadi di gerai-gerai Lippo Plaza Kota Kendari menunjukkan bahwa pengunjung merasa nyaman berada di gerai-gerai Lippo Plaza dibandingkan dengan tempat-tempat berbelanja lainnya, seperti Brilian Plaza, Rabam dan Mall Mandonga. Kenyamanan ini dirasakan oleh para pengunjung karena daya tarik dari gerai dalam Lippo Plaza tersebut sehubungan dengan desain yang disajikan kepada pengunjung. Namun, jika ditinjau dari segi tingkat harga, memang jauh berbeda antara harga-harga yang diberikan oleh gerai-gerai Lippo Plaza dibandingkan dengan tempat lain, dimana tempat lain seperti Mall Mandonga penawaran harga dapat terjadi. Sedangkan dari segi pelayanan, para pengunjung merasa lebih puas dengan pelayanan yang ada di gerai dalam Lippo Plaza yang tersaji sedemikian rupa oleh para karyawan gerai dalam Lippo Plaza.

Peritel termasuk gerai dalam Lippo Plaza wajib untuk menciptakan dan mengelola atmosfer gerai yang berkesan serta menyediakan pelayanan yang sesuai atau melebihi apa yang diharapkan konsumen. Kondisi tersebut akan dapat membantu untuk membedakan diri dan mampu menciptakan keunggulan kompetitif dari para pesaing. Pengelolaan atmosfer gerai dan pelayanan gerai yang baik akan memberikan keuntungan bagi pihak gerai dalam Lippo Plaza. Konsumen akan lebih senang berbelanja 
jika merasa nyaman ketika berinteraksi dengan lingkungan berbelanja dan kemungkinan besar akan berkunjung kembali ke suatu gerai (Soars, 2009).

Kota Kendari tak jauh beda dengan kota-kota besar lainnya di Indonesia, yakni dilihat sebagai wilayah potensial untuk ekspansi bisnis ritel. Di kota Kendari telah dibangun beberapa pusat perbelanjaan besar dan modern seperti Mall Lippo Plaza dan Mall Brilian Plaza, dan pusat-pusat perdagangan yang terdapat di kawasan Kota Kendari, dan lain-lain. Tidak dapat dipungkiri bahwa kota Kendari yang merupakan pintu gerbang Kawasan Timur Indonesia yang memiliki prospek bisnis cukup menjanjikan. Peluang bisnis itu semakin terbuka lebar sejak diberlakukannya otonomi daerah, dimana sikap pemerintah daerahnya yang sangat akomodatif terhadap para investor. Berbagai kemudahan dalam berinvestasi, seperti penyederhanaan birokrasi perijinan di berikan untuk menggaet lebih banyak investor masuk ke Kota Kendari.

Jika melihat perkembangan di Kota Kendari, sebenarnya pusat perbelanjaan yang lebih banyak menyediakan produk-produk fashion, aksesoris, dan home appliances ini tidak mengalami pertumbuhan dalam segi jumlah outlet. Pusat perbelanjaan tersebut masih tetap berjumlah tiga unit yaitu pada Mall Lippo Plaza, Mal Mandonga dan Brilian Plazza. Terbatasnya luas wilayah Kota Kendari yang diiringi dengan pertumbuhan pusat perbelanjaan serta sentra-sentra perdagangan di kota ini, telah membuat catchment area semakin sempit. Masing-masing pebisnis akan berlomba untuk mengejar konsumen dan menariknya agar mau berbelanja. Persaingan semacam ini tentu saja membutuhkan upaya strategi pemasaran yang tepat untuk menjangkau calon-calon konsumen.

Tujuan penelitian ini adalah untuk mengetahui pengaruh simultan atmosfer dan pelayanan gerai terhadap pembelian impuls pelanggan gerai dalam Lippo Plaza di Kota Kendari dan untuk mengetahui pengaruh parsial atmosfer dan pelayanan gerai terhadap pembelian impuls pelanggan gerai dalam Lippo Plaza di Kota Kendari serta untuk mengetahui variabel yang dominan mempengaruhi pembelian impuls pelanggan gerai dalam Lippo Plaza di Kota Kendari.

\section{METODE PENELITIAN}

Penelitian ini bersifat explanatory. Pada prinsipnya explanatory research melakukan explanatory dari indikator-indikator/variabel manifest yang ada, sehingga nantinya akan terbentuk faktor-faktor yang kemudian dilakukan interpretasi terhadapnya untuk menentukan variabel-variabel paten apa yang dapat kita peroleh.

Adapun objek dari penelitian ini adalah gerai dalam Lippo Plaza Kota Kendari yang berjumlah sebanyak 40 gerai, yang terdiri dari 5 (lima) cluster, yakni gerai aksesoris, gerai makanan (food court), gerai pakaian, gerai kebutuhan pokok, dan gerai entertainment. Populasi dalam penelitian ini adalah seluruh pengunjung gerai dalam Lippo Plaza Kendari yang bersifat infinitive. Penetuan sampel menggunakan teknik aksidental sampling yang ditetapkan sebanyak 40 orang responden untuk masingmasing cluster gerai, yang terdiri dari gerai aksesoris, makanan (food court), pakaian, kebutuhan pokok dan entertainment, sehingga total responden sebanyak 200 orang responden. Penentuan sampel secara sampling aksidental adalah teknik penentuan sampel berdasarkan kebetulan, yaitu siapa saja yang secara kebetulan bertemu dengan peneliti dapat digunakan sebagai sampel, bila dipandang orang yang kebetulan ditemui 
itu cocok sebagai sumber data. Penentuan sampel tersebut dengan kriteria bahwa telah melakukan lebih dari 3 kali kunjungan ke gerai dalam Lippo Plaza Kota Kendari.

Metode pengumpulan data yang digunakan: Interview (wawancara), yaitu mengumpulkan data dengan cara melakukan tanya jawab langsung dengan pihak-pihak yang terkait dalam penelitian ini. Penulis mengadakan wawancara langsung dengan manager perusahaan yang berhubungan langsung dengan masalah yang sedang diteliti, sehingga data yang dibutuhkan dalam penelitian dapat diperoleh.Angket (kuesioner), yaitu daftar pertanyaan yang telah disiapkan oleh peneliti untuk selanjutnya diberikan kepada responden untuk dijawab, dikumpulkan, ditabulasi, dan diolah kemudian disajikan.

Metode pengolahan data dalam penelitian ini: Editing, yaitu metode pengolahan data dengan cara memilih data-data yang sesuai dengan kebutuhan. Coding data, yaitu usaha mengklarifikasi data-data yang diperoleh serta jawaban-jawaban menurut jenisnya dan disesuaikan dengan kebutuhan analisa dalam penelitian. Tabulasi data, yaitu penyusunan data-data ke dalam bentuk tabel sesuai dengan kebutuhan analisa. Interprestasi, yaitu data yang telah diproses atau diolah menurut model statistik kemudian hasilnya diformulasikan dalam bentuk kalimat yang selanjutnya ditarik suatu kesimpulan yang bersifat deskriptif.

Semua item indikator yang mengukur masing-masing variabel indikator menghasilkan angka koefisien validitas yang lebih dari $0,300(r>0,30)$. Dengan demikian, dapat dinyatakan bahwa instrumen pengumpulan data yang digunakan dalam penelitian ini adalah valid. Pengujian validitas ini dengan menggunakan 30 orang responden. Semua item indikator yang digunakan untuk mengukur masing-masing variabel indikator memiliki angka koefisien yang lebih besar dari 0,600. Oleh karena itu, instrumen yang digunakan dalam mengumpulkan data dinyatakan reliabel pada taraf kepercayaan $95 \%$. Pengaruh atmosfer dan pelayanan gerai terhadap pembelian impulsif pelanggan gerai dalam Lippo Plaza di Kota Kendari dianalisis dengan menggunakan analisis regresi linear berganda sebagai berikut: $Y=a+b_{1} X_{1}+b_{2} X_{2}+$ e Dimana: $Y=$ Variabel pembelian impulsif; $X_{1}=$ Variabel atmosfer gerai; $X_{2}=$ Variabel pelayanan gerai; $\mathrm{a}=$ Konstanta; $\mathrm{b}_{1}=$ Koefisien korelasi $\mathrm{X}_{1} ; \mathrm{b}_{2}=$ Konstanta korelasi $\mathrm{X}_{2} ; \mathrm{e}=$ Faktor galat (asumsi $\mathrm{e}=0$ ). Pengujian hipotesis pengaruh variabel bebas $(X)$ secara parsial dan simultan terhadap variabel terikat (Y) digunakan uji F dan uji t. Jika nilai signifikansi $<\alpha$ 0,05 maka ada pengaruh nyata variabel bebas terhadap variabel terikat. Demikian pula sebaliknya jika nilai signifikansi $>\alpha 0,05$ maka tidak ada pengaruh nyata variabel bebas terhadap variabel terikat.

\section{HASIL PENELITIAN DAN PEMBAHASAN}

Hasil Pengujian Model Regresi Secara Simultan

Pembuktian hipotesis penelitian dilakukan mengunakan analisis regresi linear berganda. Hal ini dilakukan untuk mengetahui ada-tidaknya pengaruh secara simultan yang signifikan atmosfer gerai dan pelayanan gerai terhadap pembelian impuls oleh konsumen di gerai dalam Lippo Plaza Kendari. Hasil analisis regresi berganda yang diperoleh dapat dirangkum sebagai berikut: 
Tabel 1. Hasil Analisis Regresi Linear Berganda Pengaruh Atmosfer Gerai dan Pelayanan Gerai Terhadap Pembelian Impuls oleh Konsumen

\begin{tabular}{|c|c|c|c|c|c|}
\hline No. & $\begin{array}{c}\text { Variabel Bebas } \\
\text { (X) }\end{array}$ & $\begin{array}{l}\text { Koefisisen } \\
\text { Regresi } \\
(\beta)\end{array}$ & $t_{\text {hitung }}$ & $\mathrm{t}_{\text {signifikan }}$ & Keterangan \\
\hline $\begin{array}{l}1 \\
2\end{array}$ & $\begin{array}{l}\text { Atmosfer Gerai } \\
\left(X_{1}\right) \\
\text { Pelayanan Gerai } \\
\left(X_{2}\right)\end{array}$ & $\begin{array}{l}0,102 \\
0,718\end{array}$ & $\begin{array}{c}2,482 \\
10,133\end{array}$ & $\begin{array}{l}0,014 \\
0,000\end{array}$ & $\begin{array}{l}\text { Signifikan } \\
\text { Signifikan }\end{array}$ \\
\hline \multicolumn{2}{|c|}{$\begin{array}{l}\text { Konstanta }\left(\beta_{0}\right) \\
\text { R Square } \\
\text { R }\end{array}$} & $\begin{array}{l}1,093 \\
0,687 \\
0,829 \\
\end{array}$ & \multicolumn{2}{|c|}{$\begin{array}{l}\mathrm{F}_{\text {Sig }} \\
\text { Fhitung } \\
\text { Standar Error }\end{array}$} & $\begin{array}{l}0,000 \\
216,375 \\
2,008\end{array}$ \\
\hline
\end{tabular}

Sumber: Lampiran 5.

Hasil Pengujian Model Regresi Secara Parsial

Hasil analisis regresi linier berganda pada Lampiran 5 yang diringkas seperti pada

Tabel 1, dapat diinterpretasikan sebagai berikut:

a. Signifikansi pengaruh variabel atmosfer gerai $\left(X_{1}\right)$ terhadap pembelian impuls oleh konsumen $(\mathrm{Y})$, diperoleh nilai $\mathrm{t}_{\text {hitung }}\left(\mathrm{t}_{0,05}=2,482\right)$, dengan nilai signifikansi sebesar $t_{\text {sig }}=0,014$ yang berarti lebih kecil dari nilai $\alpha=0,050$. Hal ini mengindikasikan bahwa nilai koefisien $\beta_{1}$ sebesar 0,102 secara statistika berbeda nyata dengan nol. Karena itu, atmosfer gerai $\left(X_{1}\right)$ secara parsial berpengaruh nyata terhadap pembelian impuls oleh konsumen $(\mathrm{Y})$. Atas dasar ini pula sehingga variabel atmosfer gerai $\left(\mathrm{X}_{1}\right)$ dapat dimasukkan sebagai salah satu variabel penduga pembelian impuls oleh konsumen pada Gerai Lippo Plaza Kendari.

b. Signifikansi pengaruh variabel pelayanan gerai $\left(X_{2}\right)$ terhadap pembelian impuls oleh konsumen $(\mathrm{Y})$, diperoleh nilai $\mathrm{t}_{\text {hitung }}\left(\mathrm{t}_{0,05}=10,133\right)$, dengan nilai signifikansi sebesar $t_{\text {sig }}=0,000$ yang berarti lebih kecil dari nilai $\alpha=0,050$. Hal ini mengindikasikan bahwa nilai koefisien $\beta_{2}$ sebesar 0,718 secara statistika berbeda nyata dengan nol. Karena itu, pelayanan gerai $\left(X_{2}\right)$ secara parsial berpengaruh nyata terhadap pembelian impuls oleh konsumen $(\mathrm{Y})$. Atas dasar ini pula sehingga variabel pelayanan gerai $\left(\mathrm{X}_{2}\right)$ dapat dimasukkan sebagai salah satu variabel penduga pembelian impuls oleh konsumen pada gerai Lippo Plaza Kendari.

Berdasarkan hasil pengujian model secara parsial tersebut, maka model regresi simultan yang menyatakan pengaruh atmosfer gerai dan pelayanan gerai terhadap pembelian impuls pada gerai Lippo Plaza Kendari dapat dinyatakan sebagai berikut:

$$
Y=0,102 X_{1}+0,718 X_{2}
$$

Dimana: $Y=$ Pembelian Impuls

$\mathrm{X}_{1}=$ Atmosfer Gerai

$\mathrm{X}_{2}=$ Pelayanan Gerai

Pengujian Hipotesis

Hipotesis penelitian yang diuji adalah atmosfer gerai dan pelayanan gerai berpengaruh secara simultan terhadap pembelian impuls pada gerai Lippo Plaza Kendari. Hasil pengujian secara simultan dengan menggunakan nilai signifikansi $F$ pada 
taraf $\alpha=0,05$ sebesar $0,000\left(F_{\text {sig }}=0,000\right)$, yang berarti nilai $F_{\text {sig }}<\alpha=0,05$. Karena itu, secara keseluruhan atau secara bersama-sama variabel atmosfer gerai $\left(X_{1}\right)$, dan pelayanan gerai $\left(\mathrm{X}_{2}\right)$ berpengaruh secara signifikan terhadap pembelian impuls $(\mathrm{Y})$ pada gerai Lippo Plaza Kendari. Atas dasar ini, maka hipotesis dalam penelitian yang diajukan sebelumnya dapat diterima karena terbukti kebenarannya. Pengaruh secara parsial menunjukkan bahwa variabel atmosfer gerai dan pelayanan gerai berpengaruh simultan terhadap pembelian impuls pada gerai Lippo Plaza Kendari. Di mana pengaruh yang dominan adalah variabel pelayanan gerai memberikan nilai koefisien $\beta_{2}$ terbesar, yakni sebesar 0,718 .

Hasil penelitian sehubungan dengan karakteristik pengunjung menunjukkan bahwa pengunjung ditinjau dari segi umur, kebanyakan dalam rentang umur 19-42 tahun yaitu sebanyak 61,00 persen dari total pengunjung. Kemudian disusul 24,00 persen pengunjung yang berumur 43-54 tahun. Pengunjung dalam rentang umur antara 19-42 tahun cenderung lebih sering melakukan kegiatan berbelanja dibandingkan yang berumur 43 tahun ke atas. Penyebab terjadinya hal ini karena konsumen dalam rentang usia 19-42 tahun biasanya lebih aktif dalam mengikuti trend yang sedang berkembang. Hal ini sesuai dengan pendapat Park et al, (2006) yang mengatakan bahwa konsumen dalam rentang usia produktif (17-50 tahun) merupakan konsumen yang paling sering berbelanja impulsif.

Pengunjung ditinjau dari jenis kelamin, sebanyak 54,50 persen adalah perempuan dan sisanya yaitu sebanyak 45,50 persen adalah laki-laki. Perempuan biasanya lebih sering berbelanja dan berperilaku impulsif dibandingkan dengan laki-laki, terutama dalam hal produk fashion (Coley dan Burgess, 2003). Sedangkan pengunjung ditinjau dari segi pekerjaan, kebanyakan bekerja sebagai pegawai pemerintah atau TNI/POLRI. Pegawai pemerintah atau TNI/POLRI biasanya sudah memiliki penghasilan tetap. Penghasilan yang diperoleh sangat mempengaruhi jumlah kunjungan dan jumlah uang yang dihabiskan untuk berbelanja (Tirmizi et al., 2009).

Hasil pengujian hipotesis menunjukkan atmosfer gerai memiliki pengaruh yang signifikan terhadap pembelian impulsif yang menandakan semakin baik atmosfer gerai yang diciptakan dalam gerai Lippo Plaza maka akan dapat mendorong terjadinya pembelian impulsif pelanggan pada gerai yang bersangkutan. Temuan ini mendukung hasil penelitian sebelumnya yang dilakukan oleh Youn dan Faber (2000) yang menemukan bahwa atmosfer gerai memperbesar kemungkinan terjadinya perilaku impulsif serta penelitian oleh Soars (2009) yang menemukan adanya pengaruh positif atmosfer gerai terhadap pembelian impulsif.

Pada hipotesis ini, berdasarkan hasil pengolahan uji hipotesis yang dilakukan oleh penulis, maka terbukti bahwa atmosfer gerai gerai secara positif dan signifikan mempengaruhi timbulnya perilaku pembelian impuls. Hipotesis ini didukung oleh sebuah sumber (Kompas, Maret 2009) menyatakan bahwa lingkungan berbelanja mampu membangkitkan minat pengunjung gerai. Lingkungan tersebut mengacu pada semua karakteristik fisik dan sosial konsumen, termasuk objek fisik (produk dan gerai), hubungan ruang (lokasi gerai dan produk dalam gerai), dan perilaku sosial dari orang lain (siapa saja yang di sekitar dan apa saja yang mereka lakukan). Menurut sumber (Peter, 
1999) hal-hal yang berhubungan dengan persepsi gerai antara lain adalah penyediaan barang-barang (merchandise), pelayanan (service), fasilitas fisik (physical facilities), promosi gerai (promotion), dan kenyamanan (convenience).

Lingkungan fisik yang berupa atmosfer gerai berdasarkan hasil penelitian mempengaruhi reaksi impulsif konsumen dalam berbelanja di Lippo Plaza Kendari. Temuan penelitian ini sesuai dengan pendapat Donovan dan Rossiter (1992), Park and Lennon (2006), yang menyatakan bahwa atmosfer gerai dapat menimbulkan reaksi impulsif konsumen. Pemahaman bahwa atmosfer gerai dapat mempengaruhi reaksi impulsif karena kelengkapan produk yang ditawarkan, tata letak produk, dan pelayanan konsumen sebagai stimuli dapat menimbulkan hasrat keinginan konsumen membeli produk. Konsumen di dalam gerai Lippo Plaza Kendari berada pada suatu situasi yang dapat mendorong untuk melakukan penilaian. Proses penilaian yang dilakukan terhadap lingkungan fisik dapat menimbulkan reaksi impulsif (Kassarjian dalam Park and Lennon, 2006).

Berdasarkan uraian di atas nampak bahwa atmosfer gerai sebagai stimuli semakin kuat dipersepsikan oleh konsumen dalam memberikan informasi maka akan semakin kuat pula reaksi impulsif konsumen. Temuan tersebut mendukung pendapat yang dikemukakan oleh Park and Lennon (2006), yaitu bahwa semakin kuat atmosfer gerai memberikan informasi kepada konsumen untuk dijadikan acuan maka akan semakin kuat mempengaruhi hasrat membeli konsumen. Kondisi lingkungan atau atmosfer gerai akan berpengaruh terhadap emosional kesenangan konsumen terutama pada saat berbelanja (Babin, 1995). Pengukuran terhadap karakteristik lingkungan gerai yang spesifik akan berpengaruh tinggi pada emosional konsumen (Wakerfield, 1998). Kondisi lingkungan gerai menjadi perhatian khusus dalam kegiatan berbelanja seperti alunan musik, warna, furnitur, layout ruangan, dan kondisi elemen-elemen kecil pendukung lingkungan juga berpengaruh terhadap emosional konsumen.

Untuk menciptakan atmosfer gerai yang merangsang pembelian, sebuah retailer harus mempu membangkitkan niat atau keinginan untuk berbelanja dalam benak konsumen. Seseorang yang punya prinsip hemat pun akan lebih menyukai atmosfer gerai yang dapat merangsangnya untuk berbelanja. Atmosfer gerai adalah keseluruhan efek emosional yang diciptakan oleh atribut fisik gerai. Pada umumnya, setiap orang akan lebih tertarik pada gerai yang dapat menawarkan lingkungan berbelanja yang aman dan nyaman. Atmosfer berbelanja yang menyenangkan adalah admosfer dengan atribut yang dapat menarik kelima indra manusia, penglihatan, pendengaran, penciuman, peraba, dan perasa.

Hasil analisis pengujian hipotesis menunjukkan pelayanan gerai memiliki pengaruh yang signifikan terhadap pembelian impulsif yang berarti semakin baik pelayanan gerai yang disediakan oleh gerai Lippo Plaza Kendari maka akan dapat meningkatkan timbulnya pembelian impulsif pelanggan pada gerai tersebut. Temuan ini mendukung hasil penelitian sebelumnya yang dilakukan oleh Youn dan Faber (2000) yang menyebutkan bahwa ketersediaan fasilitas pelayanan dalam suatu gerai akan mendorong terjadinya pembelian impulsif serta penelitian oleh Fam et al. (2011) yang 
menemukan bahwa pelayanan yang disediakan oleh peritel dapat mempengaruhi terjadinya pembelian impulsif.

Hasil penelitian ini sejalan dengan pendapat Hausman (2000) menyebutkan bahwa peritel dapat mendorong terjadinya pembelian impulsif dengan menerapkan kebijakan pengembalian barang, menyediakan fasilitas pembayaran melalui kartu kredit, dan menambah jam operasional toko. Youn dan Faber (2000) menyebutkan bahwa ketersediaan fasilitas pelayanan dalam suatu gerai seperti pembayaran melalui kartu kredit dan jam operasional 24 jam akan mendorong terjadinya pembelian impulsif. Coley dan Burgess (2003) menyebutkan bahwa fasilitas yang tersedia dalam gerai seperti adanya pembayaran melalui kartu kredit, ATM, kegiatan operasional gerai 24 jam, dan jaminan uang kembali dapat memperkuat atau menciptakan godaan sehingga meningkatkan terjadinya pembelian impulsif. Fam et al. (2011) menyebutkan layanan yang disediakan oleh peritel dapat mempengaruhi terjadinya pembelian impulsif.

Peritel memiliki kemampuan untuk menciptakan perasaan emosional konsumen guna mendorong terjadinya pembelian impulsif melalui penerapan strategi bauran pemasaran yang tepat. Bauran pemasaran adalah sejumlah strategi yang dipakai oleh pengusaha untuk mencapai sasaran usahanya. Bauran pemasaran merupakan salah satu indikator yang dikendalikan oleh perusahaan agar dapat menarik konsumen untuk datang dan melakukan kegiatan berbelanja. Ma'ruf (2006) menyebutkan terdapat 6 (enam) unsur strategi bauran pemasaran dalam konteks bisnis ritel yaitu lokasi, merchandise, harga, dan promosi, atmosfer gerai, dan pelayanan ritel. Keenam unsur bauran pemasaran ritel berpengaruh terhadap keberlangsungan hidup perusahaan dan dapat dipakai untuk menciptakan nilai tambah perusahaan dibandingkan para pesaingnya.

\section{KESIMPULAN}

Penelitian ini menunjukan bahwa terdapat pengaruh yang signifikan atmosfer gerai terhadap pembelian impulsif pada gerai dalam Lippo Plaza Kendari. Hal ini memberikan arti bahwa atmosfer gerai memberikan kontribusi yang signifikan terhadap pembelian impulsif. Berdasarkan hasil tersebut, dapat disimpulkan bahwa hipotesis penelitian yang menyatakan "atmosfer gerai berpengaruh signifikan terhadap pembelian impulsif pada gerai dalam Lippo Plaza Kendari" dapat diterima. Terdapat pengaruh yang signifikan pelayanan gerai terhadap pembelian impulsif pada gerai dalam Lippo Plaza Kendari. Hal ini memberikan arti bahwa pelayanan gerai memberikan kontribusi yang signifikan terhadap pembelian impulsif pada gerai dalam Lippo Plaza Kendari. Berdasarkan hasil tersebut, dapat disimpulkan bahwa hipotesis penelitian yang menyatakan "pelayanan gerai berpengaruh signifikan terhadap pembelian impulsif pada gerai dalam Lippo Plaza Kendari" dapat diterima. Hasil analisis menunjukkan bahwa secara bersama-sama kedua variabel bebas yakni atmosfer dan pelayanan gerai memberikan pengaruh yang signifikan terhadap pembelian impulsif pada gerai dalam Lippo Plaza Kendari. Setiap peningkatan atmosfer dan pelayanan gerai akan diikuti pula peningkatan pembelian impulsif pada gerai dalam Lippo Plaza Kendari. 


\section{UCAPAN TERIMA KASIH}

Penulis mengucapkan terima kasih kepada Lembaga Penelitian dan Pengabdian Kepada Masyarakat (LPPM), Universitas Muhammadiyah Kendari yang telah memberikan dukungan finansial dalam penelitian ini.

\section{DAFTAR PUSTAKA}

Abednego, 2011. Analisis Pengaruh Atmosfer Gerai Terhadap Penciptaan Emosi, Perilaku Belanja, dan Terhadap Pendekatan Perilaku. Fokus Ekonomi, Agustus, 2011.

Alma, B. 2005. Manajemen Pemasaran, Jilid II, Edisi Kesebelas. Jakarta: PT. Indek Kelompok Gramedia.

Assauri, Sofyan, 1998. Manajemen Pemasaran dasar, Konsep dan Strategi, CV. Rajawali, Jakarta.

Astuti, R. D., dan Fillippa, M. 2008. Perbedaan pembelian secara impulsif berdasarkan tingkat kecenderungan, kategori produk dan pertimbangan pembelian, Jurnal Ichsan Gorontalo Volume 3 No.1, pp.1441-1456.

Babin, B.J., and Jill, S.A. 1995. Atmospheric Effect as a Tool for Creating Value and Gaining Share of Customer, Journal of Business Research,Volume 49, pp 91-99.

Ballantine, P. W., Jack, R., and Parsons, A. G. 2010. Atmospheric Cues and Their Effect On The Hedonic Retail Experience, International Journal of Retail and Distribution Management Vol. 38 No. 8, pp. 641-653.

Bayley, G. and Nancarrow, C. 1998. Impulse Purchasing: A Qualitative Exploration of The Phenomenon, Qualitative Market Research: An International Journal Volume 1 Number 2, pp. 99-114

Beatty, S. E., and Ferrell, M. E. 1998. Impulse Buying: Modeling Its Precusors, Journal of Retailing Vol. 74 No. 2. Pp. 169-191.

Berman, Barry dan Joel R. Evans, 2001. Retail Management: A strategic Approach, Eighth Edition. Precentice Hall, New Jersey.

Coley, A. and Burgess, B. 2003. Gender Differences In Cognitive And Affective Impulse Buying, Journal of Fashion Marketing and Management Vol. 7 No.3, pp. 282-295.

Dharmamesta, B. \& Irwan, 2000. Loyalitas Pelanggan: Sebuah Kajian Konseptual Sebagai Panduan Bagi Peneliti. Jurnal Ekonomi dan Bisnis Indonesia. Vol 14 No.3, pp7388.

Donovan, Robert.J., Rossiter. 1992. "Store Athmosphere: An Environmental Psychology Approach." Journal of Retailing, Spring.

Engel, James F, Blackwell Roger D, Miniard, Paul W, 1994, Perilaku Konsumen, Alih Bahasa F.X. Budiyanto, Penerbit Binarupa Aksara, Jakarta.

Fam, K. S., Merrilees, B., Richard, J. E., Jozca, L., Li, Y., and Krisjanous, J. 2011. In-Store Marketing: A Strategic Perspective, Asia Pasific Journal of Marketing and Logistics Vol. 23 No.2, pp. 165-176.

Grayson, R. A. S. and McNeill, L. S. 2009. Using Atmospheric Elements in Service Retailing: Understanding The Bar Environment, Journal of Services Marketing 23/7, pp. 517-527.

Hausman, A. 2000. A Multi-Method Investigation of Consumer Motivations in Impulse Buying Behavior. Journal of Consumer Marketing Vol. 17 No.5, pp. 403-19. 
Harmancioglu, N., Finney, R. Z., and Joseph, M. 2009. Impulse Purchases of New Product: An Empirical Analysis, Journal of Product and Brand Management 18/1, pp. 2737.

Herabadi, A. G. 2003. Buying Impulses: A Study on Impulsive Consumption, Disertasi, Social Psychological Department, Catholic University of Nijmegen, Belanda.

Hetharie, 2012. Pengaruh Stimulus Lingkungan dan Sosial Toko Terhadap Emosi Positif dan Impulsif Buying. Journal Ekonomi. Julki 2003.

Kacen, J. J., and Lee, J. A. 2002. The Influence of Culture on Consumer Impulsive Buying Behavior, Journal of Consumer Psychology 12(2), pp. 163-176.

Kotler, Philip, 1993. Manajemen Pemasaran : Analisis Perencanan,Implementasi, Pengendalian, Jilid I Edisi III, Fakultas Ekonomi UI, Jakarta.

., 2006. Marketing Management, The Millenium Edition, Prentice-Hall, Inc, New Jersey.

2002. Marketing, Erlangga, Jakarta.

Kusumowidagdo, 2010. Pengaruh Desain Atmosfer Toko terhadap Perilaku Belanja (Studi atas Pengaruh Gender Terhadap Respon Pengunjung Toko). Universitas Ciputra, Jakarta.

Lamb, Charles W, Hair, Joseph F dan Mc. Daniel, Carl, 2001. Pemasaran, Edisi dua, Salemba Empat, Jakarta.

Levy, Michael dan Barton A. Weitz, 2009. Retailing Management, Fourth Edition, Mc graw-Hill.

Ma'ruf, H. 2006. Pemasaran Ritel. Jakarta: PT.Gramedia Pustaka Utama.

Mangkunegara Anwar Prabu, 1998. Perilaku Konsumen, Cetakan Kedua, Ghalia, Jakarta.

Mattila, A. S. and Wirtz, J. 2008. The Role of Store Environmental Stimulation and Social Factors on Impulse Purchasing, Journal of Services Marketing 22/7, pp. 562-567.

Park, E. J., Kim, E. Y., and Forney, J. C. 2006. A Structural Model of Fashion-Oriented Impulse Buying Behavior, Journal of Fashion Marketing and Management Vol. 10 No. 4, pp. 433-446.

Park, J. and Lennon, S. J. 2006. Psychological and Environmental Antecedents of Impulse Buying Tendency in The Multichannel Shopping Context, Journal of Consumer Marketing 23/2, pp. 58-68.

Peter, Paul., Jerry C. Olson., 1999. Consumer Behavior and Marketing Strategy. McGraw Hill: United States.

Rintamaki, T., Kanto, A., Kuusela, H., and Spencer, M. T. 2006. Decomposing the value of department store shopping into utilitarian, hedonic and social dimensions, International Journal of Retail \& Distribution Management Vol .34 No.1, pp. 621.

Rohman, F., 2009. Peran Nilai Hedonik Konsumsi dan Reaksi Impulsif Sebagai Mediasi Pengaruh Faktor Situasional Terhadap Keputusan Pembelian Impulsif di Butik Kota Malang. Tesis. Brawijaya, Malang.

Santoso, S. 2007. Riset Pemasaran (Konsep dan Aplikasi dalam SPSS). Jakarta : PT. Alex Media Komputindo.

Semuel, H. 2005. Respon Lingkungan Berbelanja Sebagai Stimulus Pembelian Tidak Terencana Pada Toko Serba Ada (Toserba): Studi Kasus Carrefour Surabaya, Jurnal Manajemen dan Kewirausahaan Vol. 7 No. 2, pp. 152-170. 
Semuel, H. 2006. Dampak Respon Emosi Terhadap Kecenderungan Perilaku Pembelian Impulsif Konsumen Online Dengan Sumberdaya yang Dikeluarkan dan Orientasi Belanja Sebagai Variabel Mediasi, Jurnal Manajemen dan Kewirausahaan Vol. 8 No.2, pp. 101-115.

Silvera, D. H., Lavack, A. M., and Kropp, F. 2008. Impulse Buying: The Role of Affect, Social Influence, and Subjective Wellbeing, Journal of Consumer Marketing 25/1, pp. 23-33.

Soars, B. 2009. Driving sales through shopper's sense of sound, sight, smell, and touch, International Journal of Retail and Distribution Management, Vol. 37 No.3, pp. 286-298.

Sopiah dan Syihabudhin. 2008. Manajemen Bisnis Ritel. Yogyakarta: ANDI

Sugiyono. 2007. Metode Penelitian Bisnis. Cetakan kesembilan. Bandung: CV Alfabeta

Sutisna, 2002. Perilaku Konsumen dan Komunikasi Pemasaran. Remaja Rosdakarya, Bandung.

Swastha, Basu, DH., 2000. Asas-asas Marketing, Edisi III, Yogyakarta: Liberty.

Swastha dan Handoko, 1987. Manajemen Pemasaran: Analisis Perilaku Konsumen. Liberty, Yogyakarta.

Swastha, Basu dan Irawan, 2000. Manajemen Pemasaran Modern, Edisi 3, Yogyakarta: Liberty.

Tjiptono, Fandy, 2005. Manajemen Jasa. Andi Offset, Yogyakarta.

Tirmizi, M. A., Rehman, K. U., and Saif, M. I. 2009. An Empirical Study of Consumer Impulse Buying Behavior in Local Markets, European Journal of Scientific Research ISSN 1450-216X Vol. 28 No. 4, pp. 522-532.

Utami, C. W. 2010. Manajemen Ritel: Strategi dan Implementasi Operasional Bisnis Ritel Moderen di Indonesia. Jakarta: Salemba Empat.

Wakefield, L. Kirik., Julie Baker., 1998. "Excitement at the Mall: Determinant and Effect on Shopping Response". Journal of Retailing, New York, Vol 74.

Winardi, 1993. Azas-azas Marketing, Cetakan Kedua. Alumni, Bandung.

Youn, S. and Faber, R. J. 2000. Impulse Buying: Its Relation to Personality Traits and Cues, Advances in Consumer Research Volume 27, pp. 179-185

Yudatama et al, 2007. Pengaruh Store Image, trore Atmospherics, Store Theatrics, dan Social Factors Terhadap Pembelian Tidak Terencana (Studi Kasus Pada Luwes Pasar Swalayan Ungaran). Jurnal Ilmu Administrasi Bisnis. Semarang.

Yustiani, dkk., 2012. Pengaruh Atmosfer Gerai dan Pelayanan Retail Terhadap Nilai Hedonik dan Pembelian Impulsif. Journal Manajemen, Strategi Bisnis dan Kewirausahaan. Vol 6 No. 2 Agustus 2012.

Zhang, Y., Sirion, C., and Combs, H. 2011. The influence of the mall environment on shopper's values and consumer behavior in China, ASBBS Annual Conference, Vol. 18 No. 1, pp. 214-224 